* Artigo Original

\title{
A community profile of Internet use in a low-income health clinic in Rio de Janeiro, Brazil
}

\section{O perfil de uso da Internet entre moradores de uma comunidade de baixa renda em um posto de saúde no Rio de Janeiro, Brasil}

\section{Andre Pereira Neto}

Graduação em História pela Pontifícia Universidade Católica do Rio de Janeiro, Mestrado em História - Universite de Paris III (Sorbonne-Nouvelle), Doutorado em Saúde Coletiva pela Universidade do Estado do Rio de Janeiro e Pós-Doutorado em Sociologia da Saúde pela Universidade da Califórnia, San Francisco.

apereira@fiocruz.br

\section{Alexandra Melo}

Estudante de Graduação do Departamento de Saúde Internacional da Universidade de Georgetown, em Washington DC, Estados Unidos da América.

melon.ale@gmail.com

\section{Allyson Noyes}

Estudante de Graduação do Departamento de Saúde Internacional da Universidade de Georgetown, em Washington DC, Estados Unidos da América.

noyes.al.noyes@gmail.com

DOI: $10.3395 /$ reciis.v7i2.800en

\begin{abstract}
The Internet has revolutionized how people communicate and access information. As this technology becomes increasingly widespread and affordable around the world, it is fundamental to understand how and why people access information online and the role it plays in daily life. Gaps in both Internet access and literacy may further polarize socioeconomic groups. This study sought to create a community profile on Internet use and health-seeking behavior in a low-income population. Researchers conducted both oral questionnaires $(n=102)$ and qualitative interviews $(n=17)$ at a public primary health clinic that caters to a nearby slum complex, during a four-week time period. Of all participants, $60.8 \%$ reported using the Internet. The study found that Internet use for health-related information and help was present but not prevalent among participants. According to this study, doctor-patient relationships have only partially permeated the virtual sphere, yet knowledge of available online health information is widespread. Results in this study encourage the use of Internet resources in the implementation of community level public health interventions.
\end{abstract}


Keywords: Internet, Physician-patient relations, Primary Health Care, Information Seeking Behavior, Information Technology.

\section{Resumo}

A Internet revolucionou a forma como as pessoas se comunicam e acessam informações. Esta tecnologia tem se tornado cada vez mais difundida e acessível em todo o mundo. Por esta razão é fundamental que se compreender como e por que as pessoas buscam informações online. É importante também compreender o papel que estas informações desempenham na vida diária do cidadão. As dificuldades financeiras e técnicas de acesso à Internet e os problemas alfabetização digital podem polarizar ainda mais os grupos socioeconômicos. Este estudo procurou construir um perfil de uma determinada comunidade sobre o uso da saúde na Internet analisando o comportamento de uma população de baixa renda. Os pesquisadores realizaram dois questionários orais $(n=102)$ e entrevistas qualitativas $(n=17)$ em uma clínica pública de atenção primária à saúde que atende a um complexo de favelas durante quatro semanas. Ao todo, $60,8 \%$ dos participantes já acessaram a Internet. 0 estudo constatou que o uso da Internet para a busca de informações relacionadas com a saúde está presente, mas não é prevalente entre os participantes. De acordo com este estudo, relação médico-paciente é permeada parcialmente pela esfera virtual. Os resultados obtidos neste estudo incentivam o uso dos recursos disponíveis na Internet nas intervenções que afetem a saúde da comunidade.

Palavras Chave: Internet relação médico-paciente, Atenção Primária à Saúde, Comportamento de Busca de Informação,Tecnologia da Informação.

\section{Introduction}

As the world becomes increasingly digitized and as more activities are carried out via the Internet, politicians and sociologists have identified a phenomenon known as the "digital divide." This term refers to the factors and differences that influence the access and use of communication technology, be it socioeconomic, language, age, ability, geography, etc. (GUTIÉRREZ and GAMBOA, 2010). Some argue that "[the digital divide is] less about access to technology and more about participation," which refers to digital literacy, the skills needed to comprehend the Internet once access is obtained (JAEGER, 2012). To combat populations slipping below digital literacy levels, politicians now talk about digital inclusion policies created to increase access and improve Internet literacy (JAEGER, 2012). A recent study found that relatively rich countries, like Brazil, are closing the absolute Internet digital divide whereas in poorer regions, like sub-Saharan Africa, the absolute divide is increasing (JAMES, 2011).

Indeed, Brazil as a country has made enormous strides in decreasing the digital divide. In 2006, 33\% of all Brazilians reported accessing the Internet; by $201153 \%$ reported using the Internet (CETIC, 2011). Overwhelmingly, the increase in use came from the poorest populations. Between 2006 and 2011, those in the highest economic class saw little difference in the percentage of individuals who accessed Internet $(94 \%)$ but the lowest two social classes, $C$ and DE Internet use increased from $38.8 \%$ to $54 \%$ and $12.2 \%$ to $21 \%$ between 2006 and 2011, respectively (CETIC, 2011). More than double the population of the poorest Brazilians nationally now access the Internet. Therefore, a paradigm shift among research and interventions must occur to access these populations in the earliest stages of Internet use to include them in the public health profile. Despite these strides, there are still stark inequalities between socioeconomic and geographic areas. 
Among those that have accessed the Internet, activities remain similar between social classes. In all of Brazil, $69 \%$ of those with Internet access have used an online social network. Of the lowest social class, $63 \%$ had ever accessed compared to $71 \%$ of the wealthiest Brazilians (CETIC, 2011). This indicates that although a wide digital divide still exists in Brazil, the levels of digital literacy among socio-economic classes are much closer than expected. This research seeks to explore this phenomenon and to examine digital literacy levels among the poorest Brazilians while also investigating where digital divides still persist. These populations live in peri-urban areas of large cities, in favelas with precarious sanitation and safety conditions. Often, telephone lines do not operate properly for all inhabitants.

Manguinhos is a low-income slum complex favela located in North Zone Norte in Rio de Janeiro, Brazil. It is well known for its drug-related violence, and much effort has been in place to combat this violence and mobilize the community. It is comprised of 12 different communities with different socio-economic profiles. Each community has different living conditions and social indicators marked by large contrasts. However, unemployment, job insecurity, informal work, low per capita income, low health and education indicators, adult illiteracy poor living and sanitation conditions, a lack of cultural and leisure activities and the influence of drug trafficking are common traits in each of these communities. These indicators reveal the absence or lack of basic services. Thus, the population that lives in the Manguinhos Complex can be considered a typifying example of the majority of poor Brazilians. There are huge health inequalities between Manguinhos and wealthier areas of Rio; for example, dengue cases in Manguinhos were 4.7 times higher than cases in Leblon (one of the wealthiest neighborhoods) and 2.8 times higher than Maré, which has a similar socio-economic picture (LTM, 2012) status (TRINIDADE, 2012 ENSP, 2006). The community is also known for its proximity to Oswaldo Cruz Foundation (Fiocruz) - (Fundação Oswaldo Cruz), a research institution in microbiology, parasitology and public health, that produces vaccines, medicines and has a hospital and primary health clinic for the Manguinhos population.

\section{Literature Review}

Though most research on Internet and health has focused on wealthy populations, some preliminary studies have examined health-seeking behavior in lower-income and developing regions. Widespread, relatively inexpensive access to the Internet has enormous public health implications, particularly for disseminating information (COURSARIS et al., 2009; SAMAL et al. 2010; SMITH-MENEZES et al., 2012). Individuals who reported accessing online social networks or health-related information had better social and active coping, disease knowledge, and social support (COURSARIS et al., 2009; Kalichman et al., 2002). A study in the Uganda found that $45 \%$ of youth had used the Internet and a third of total respondents reported had used a computer to search for HIV/AIDS information (YBARRA, 2006). However, like any technological advance, there are unintended consequences of this rapidly available information. Studies have found chat rooms used for discussion of benzydamine abuse to induce hallucinations and fraudulent websites often target uneducated populations with desperate medical conditions (SOUZA, 2008; VASCONCELLOS-SILVA, 2011).

Research has overwhelmingly found an association between education level and Internet use. One study found that across Colombia, Mexico and Peru, the single greatest limiting factor of low-income people was lack of education (GUTIÉRREZ and GAMBOA, 2010). Another study looking at HIV/AIDS patients' evaluation of health information found that poor reading comprehension, lower literacy levels and lower income and educational attainment was associated with assigning credibility to low-quality information (BENOTSCH, 2004). Studies have also found that women are more likely than men to look for health information on the Internet (GARBIN et al., 2008). 
Internet access also has important implications on the doctor-patient relationship, how patients access health information and their beliefs about this information (GARBIN et al., 2008). Lower income and lower educational achievement is associated with assigning credibility to websites that medical professionals do not (BENOTSCH et al., 2004). Though certain social network use can be detrimental to health, other studies have found positive health correlations with social network use. A recent study by Rossotti et al. (2012) suggests using Facebook as an education and counseling strategy for people living with HIV/AIDS. By encouraging use of a social-media platform to communicate with patients, it broke the paradigm of one-way messages from experts to individuals that has characterized "e-health communication" for the past decade (ROSSOTTI et al., 2012). Research has also found a possible link between online communication and positive behavior changes through social networks such as forums rather than one-way communication channels, like an expert talking to an individual (NEUHAUSER and KREPS, 2003). Studies have also found that patients are no longer passive recipients of health information, meaning they actively search for information on their own, usually on the Internet (GARBIN et al., 2008). Opinions and research results show disagreement regarding the role of health professionals in their patients Internet health seeking behavior. One study found that health professionals must be aware of their patients' health information seeking behavior and possess the tools to enhance their experience online (McMullan, 2006). Another study by Kim and Kim (2009) found that online health-seeking behavior has a neutral result on the doctor-patient relationship. Despite doctor-patient relationships online and frequent online health-seeking behavior, a study by Välimäki et al. (2007) found that patients prefer to receive information face-to-face from a health professional.

\section{Methods}

\section{Participants}

A convenience sample of Manguinhos residents was recruited from the Primary Care health clinic waiting room during a four-week time period in October-November 2012. Using the public health clinic within the community allowed the researchers to study a low-income population with access to universal health care services, while representing a range of ages, education status, neighborhoods, and gender. The following criteria were used to recruit participants: (1) be older than 18 years old; (2) be a current resident of the Manguinhos community (3) be able to give verbal consent in Portuguese. In addition, interview participants were required to self identify as Internet users.

\section{Design}

This study used a mixed-method approach. For quantitative questionnaires, the researchers carried out three rounds of pilot studies to test the readability and comprehension of the questionnaire. After refining and consulting both research experts and community members, a final questionnaire was developed. At the end of each round of interviews, the researchers quantified age and sex to target demographic pockets that had been yet untapped. The researchers read aloud questions to participants and marked the answer given by the individual. Each questionnaire took approximately 15 minutes to complete. The interview script was tested for cultural sensitivity and comprehension in two rounds of pilot studies that led to the final script used in this study. Interviews were conducted after questionnaire analysis to prepare the researchers for preliminary findings regarding how and why community members access the Internet. Each interview lasted between 6-25 minutes, with a mean time of 10:40 minutes. The "Research Ethics Committee" (CEP) at the National School of Public Health (ENSP) in Rio de Janeiro, Brazil approved all research methods and materials for this study. All 
data collection occurred in the waiting room of the Primary Care Health Center (CSEGNF) associated with ENSP.

\section{Measures}

Quantitative. Questions regarding health perception were adopted from the SF-36 health survey. This generic measure is meant to measure physical, mental and emotional health with no bias toward age, disease or treatment group (WARE, 2002). This English-language survey was consulted, as was the Portuguese translated version of the SF-36 (FERREIRA, 2000). The researchers consulted the Community Health Workers (Agentes Comunitários de Saúde) to discuss a preliminary version of the questionnaire. After receiving their input, the researchers designed the questionnaire and conducted three rounds of pilot studies to determine comprehension and applicability of the questionnaire.

Questions regarding Internet use were developed from the 2011 "Technology, Information and Communication Households and Businesses Survey" conducted by the Brazilian Internet Steering Committee (CGI). This Committee was created (1995) with the purpose of coordinating and integrating all Internet service initiatives in Brazil, as well as promoting technical quality, innovation and the dissemination of available services. This nationwide survey began in 2005 and the latest available data is from 2011. Questions include types of Internet use, location of access, duration of access and frequency of Internet use. The researchers developed Internet use questions from this survey with the input of experts in the field of Internet communication.

Qualitative. The researchers developed an interview script with 15 questions that pertain to health perception and Internet use for general and health-related purposes. Every interview began with the question "What is the importance and meaning of health?" and ended with a version of "What kind of relationship exists between your health and the Internet?" The goal of the script was to understand individuals' perception of the role of the Internet in their lives, as well as their relationships with and within social networks and online chatting, their experiences with Internet research and their perception of doctor-patient relationships.

\section{Data Analysis}

Quantitative. All questionnaires were completed in their entirety barring those who had never accessed the Internet who were exempt from the final section of the questionnaire. Questionnaires were manually entered in SPSS, an IBM quantitative data analysis software. The researchers first tested associations among education level, sex and age for any significant associations. Education level and age were multicollinary and therefore excluded from the multiple regression analysis. Because education level and income are fairly uniform among this population, the researchers excluded these indicators from further analysis and focused instead on age and sex. Data collected was then compared to a national survey on Internet use conducted by CGI.

Qualitative. Transcribed interviews were analyzed thematically to arrive at a rich description and understanding of the data. The researchers coded interviews in Portuguese and then reverse translated select quotes to English. The analysis was developed in three main stages where the researchers went from broad descriptive codes to themes that depict trends in Internet use among Manguinhos residents. The first codes were modeled after questions from the interview script. After the first coding phase, the data was recorded by frequency of codes. At this stage, some of the original codes were eliminated due to lack of informative data. The third stage of analysis focused on interpreting themes from the existing codes. Finally, themes were labeled according to the main findings in the study. 
Qualitative. A total of seventeen interviews were conducted with twelve women and five men that self-identified as Internet users. Of the seventeen, the researchers classified four as young adults, eleven as adults, and two as elderly. The youngest participant was nineteen years old and the oldest was seventy years old. Most participants were Brazilian nationals with the exception of a Portuguese immigrant; thus, all interviews were conducted in Portuguese. All quotes have been reverse translated into English by the researchers and her advisor. Qualitative results are arranged thematically to highlight the true nature of Internet use in the study population. The first theme describes peoples' use and relationship with the Internet. The second theme studies the Doctor-patient relationship and the cognitive dissonance that arises when the doctor-patient relationship is taken to the virtual sphere. The last theme attempts to outline how participants perceive the value of the Internet in their lives.

\section{Results}

A total of 119 individuals were sampled; 102 completed the quantitative questionnaire (27 men and 75 women) and 17 participated (12 women and 5 men) in the qualitative interview. The mean level of education was incomplete high school and average monthly income was no more than $\mathrm{R} \$ 600$ (US\$300) (see Table 1 below).

Table 1: Demographic characteristics of Manguinhos residents

\begin{tabular}{|c|c|c|}
\hline & \\
\hline & $\mathbf{N}$ & Percentage \\
\hline \multicolumn{3}{|l|}{ Sex } \\
\hline Male & 27 & 26.5 \\
\hline Female & 75 & 73.5 \\
\hline \multicolumn{3}{|l|}{ Age } \\
\hline $18-24$ & 22 & 21.6 \\
\hline $25-30$ & 19 & 18.6 \\
\hline $31-40$ & 16 & 15.7 \\
\hline $41-50$ & 16 & 15.7 \\
\hline $51-60$ & 16 & 15.7 \\
\hline $60+$ & 13 & 12.7 \\
\hline \multicolumn{3}{|l|}{ Education } \\
\hline None & 2 & 2.0 \\
\hline Incomplete primary school & 26 & 25.5 \\
\hline Complete primary school & 17 & 16.7 \\
\hline Incomplete high school & 38 & 37.3 \\
\hline Complete high school & 19 & 18.6 \\
\hline
\end{tabular}




\begin{tabular}{l|l|l}
\hline \multicolumn{2}{l}{ Monthly income } & \multicolumn{2}{l}{} \\
\hline Varies & 8 & 7.9 \\
Less than $\mathrm{R} \$ 300$ & 4 & 4.0 \\
$\mathrm{R} \$ 300-\mathrm{R} \$ 400$ & 10 & 9.9 \\
$\mathrm{R} \$ 400-\mathrm{R} \$ 500$ & 4 & 4.0 \\
$\mathrm{R} \$ 500-\mathrm{R} \$ 600$ & 17 & 16.8 \\
More than $\mathrm{R} \$ 600$ & 58 & 57.4 \\
\hline Total & 102 & 100.0 \\
\hline
\end{tabular}

Of the 102 residents interviewed, 73,5\% were female $(\mathrm{N}=75)$ and $26,5 \%$ were male $(\mathrm{N}=27)$. The average age was 32 years old. All interviewees were native Brazilians. Most (37.3\%) residents had completed some high school but had not finished their degree. Slightly more than half $(57.4 \%)$ of residents made more than $\mathrm{R} \$ 600$ (US\$300) per month, the minimum wage (see table 1 above).

Sixty-two Manguinhos residents $(60,8 \%)$ had accessed the Internet. These results were slightly higher than the findings of the national survey, where $53 \%$ had accessed the Internet. The most common access location was at home $(67,7 \%)$ with someone else's home $(14,5 \%)$ and a LANHouse (public paid access) $(14,5 \%)$ second most common. Frequency of use was split between those who use the Internet ever day $(38,7 \%)$ and those who use the Internet less than once a week (35,5\%). The average time of access was 3 years. Across Brazil, $59 \%$ reported their home as a primary access location and $14 \%$ reported using a LANHouse most frequently, without adjusting for income or location. The CGI study (2011) found that $66 \%$ of Brazilians use the Internet every day and $25 \%$ use it a few times a week (see Table 2.1 below).

Table 2.1: Ever accessed the Internet: Mangunihos and National

\begin{tabular}{|c|c|c|c|}
\hline & \multicolumn{2}{|c|}{ Manguinhos } & \multirow{2}{*}{$\begin{array}{c}\text { National } \\
\text { Percentage }\end{array}$} \\
\hline & $\mathbf{N}$ & Percentage & \\
\hline Yes & 62 & 60,8 & 53,0 \\
\hline No & 40 & 39,2 & 47,0 \\
\hline
\end{tabular}

Table 2.2: Prevalence of key indicators among Internet users: Manguinhos and National Average

\begin{tabular}{c|c|c}
\hline \multicolumn{2}{c|}{ Manguinhos } & National (2011) \\
\hline N & Percentage & Percentage \\
\hline
\end{tabular}

Primary access location

\begin{tabular}{l|l|l|l}
\hline At home & 42 & 67,7 & 59 \\
\hline
\end{tabular}




\begin{tabular}{l|l|l|l}
\hline Someone else's house & 9 & 14,5 & 8 \\
\hline Work & 5 & 8,1 & 12 \\
\hline School & 2 & 3,2 & 3 \\
\hline Mobile (i.e. cell phone) & 3 & 4,8 & 2 \\
\hline LANHouse $^{1}$ & 9 & 14,5 & 14 \\
\hline Free public access & 2 & 3,2 & 1 \\
\hline
\end{tabular}

Frequency of use in the past week

\begin{tabular}{l|l|l|l}
\hline Every day & 24 & 38,7 & 66 \\
\hline $4-5$ times a week & 4 & 6,5 & 25 \\
\hline 2-3 times a week & 14 & 22,6 & - \\
\hline Less than 1 time & 22 & 35,5 & - \\
\hline Not in the past week & 8 & 12,9 & 2 \\
\hline
\end{tabular}

How long with Internet access

\begin{tabular}{l|l|l|l}
\hline 6 months & 6 & 9,7 & - \\
\hline 1 year & 12 & 19,4 & - \\
\hline $2-3$ years & 22 & 35,5 & - \\
\hline $4-5$ years & 6 & 9,7 & - \\
\hline More than 5 years & 26 & 41,9 & - \\
\hline
\end{tabular}

Of those who had ever used the Internet, $85.9 \%(\mathrm{~N}=61)$ had ever used a search engine, like Google, for research. Most common use of the Internet for health-based research was researching an illness (70,9\%) and researching nutrition information $(67,7 \%)$ (Table 3 ). However, these results also demonstrated that individuals are more often passive receivers of information rather than actively informing others about health. Forty-one of respondents had ever received health information via email or a social network while only $30,6 \%$ had ever informed someone else about health or health information (see Table 3 below).

Table 3: Internet-based health-seeking behavior among Internet users in Manguinhos

\begin{tabular}{l|l|l}
\cline { 2 - 3 } & N & \multicolumn{1}{c}{ Percentage } \\
\hline Researched an illness & 44 & 70,9 \\
Researched nutrition & 42 & 67,7 \\
Researched exercise & 34 & 54,8 \\
Exchanged health information via the Internet & 26 & 41,9
\end{tabular}


\begin{tabular}{l|l|l} 
Informed someone about health (via e-mail, social network, IM, etc.) & 21 & 33,9 \\
Received health information (via e-mail, social network, IM, etc.) & 26 & 41,9 \\
Posted health information (via e-mail, social network, IM, etc.) & 19 & 30,6 \\
\hline
\end{tabular}

The Internet was most often used for communication and social activities. Seventy-one percent of respondents reported having ever used email and $85 \%$ reported ever having used a social network, with Facebook and Orkut (a Brazilian social networking site) as the most often visited sites. Nationally, email use is slightly higher (79\% of Internet-users surveyed had ever used email) and social network use was slightly lower (69\% of respondents) (table 4). Using instant messaging services, like MSN, was also relatively common in the population, with $66 \%$ reporting ever having chatting with someone else online, compared with $74 \%$ of those in the CGI nation-wide survey. Video chatting either with MSN or other services like Skype was less common with only $17 \%$ of respondents having ever used video chat, compared with $37 \%$ of those across Brazil.

Table 4: Prevalence of activities on the Internet

\begin{tabular}{|c|c|c|c|c|c|c|c|c|c|}
\hline & \multicolumn{2}{|c|}{$\begin{array}{l}\text { Sending and } \\
\text { receiving } \\
\text { emails }\end{array}$} & \multicolumn{2}{|c|}{$\begin{array}{l}\text { Sending } \\
\text { instant } \\
\text { messages }\end{array}$} & \multicolumn{2}{|c|}{$\begin{array}{l}\text { Taking part } \\
\text { in social } \\
\text { networks }\end{array}$} & \multicolumn{2}{|c|}{$\begin{array}{l}\text { Talking to } \\
\text { people on } \\
\text { Skype }\end{array}$} \\
\hline \multirow{2}{*}{\multicolumn{2}{|c|}{$\begin{array}{l}\text { Total Brazil (\%): } \\
\text { Total Manguinhos (\%): }\end{array}$}} & \multirow{2}{*}{\multicolumn{2}{|c|}{$\begin{array}{l}79 \\
71\end{array}$}} & \multirow{2}{*}{\multicolumn{2}{|c|}{$\begin{array}{l}74 \\
66\end{array}$}} & \multirow{2}{*}{\multicolumn{2}{|c|}{$\begin{array}{l}69 \\
85\end{array}$}} & \multirow{2}{*}{\multicolumn{2}{|c|}{$\begin{array}{l}17 \\
37\end{array}$}} \\
\hline & & & & & & & & & \\
\hline & & $\begin{array}{c}\text { Brazil } \\
(\%)\end{array}$ & $\begin{array}{c}\text { Mang. } \\
(\%)\end{array}$ & $\begin{array}{c}\text { Brazil } \\
(\%)\end{array}$ & $\begin{array}{c}\text { Mang. } \\
(\%)\end{array}$ & $\begin{array}{c}\text { Brazil } \\
(\%)\end{array}$ & $\begin{array}{l}\text { Mang. } \\
(\%)\end{array}$ & $\begin{array}{c}\text { Brazil } \\
(\%)\end{array}$ & $\begin{array}{c}\text { Mang. } \\
(\%)\end{array}$ \\
\hline \multirow[t]{2}{*}{ Sex } & Male & 80 & 70 & 74 & 67 & 69 & 89 & 19 & 44 \\
\hline & Female & 78 & 75 & 74 & 63 & 70 & 75 & 15 & 35 \\
\hline \multirow{3}{*}{$\begin{array}{l}\text { Level of } \\
\text { education }\end{array}$} & None & 60 & 50 & 54 & 20 & 57 & 80 & 9 & 30 \\
\hline & $\begin{array}{l}\text { Primary } \\
\text { school }\end{array}$ & 69 & 44 & 71 & 44 & 73 & 56 & 11 & 0 \\
\hline & High school & 80 & 81 & 76 & 81 & 71 & 93 & 16 & 47 \\
\hline \multirow[t]{5}{*}{ Age group } & $18-24$ & 82 & 82 & 82 & 86 & 82 & 95 & 20 & 32 \\
\hline & $25-34$ & 86 & 74 & 77 & 63 & 70 & 89 & 19 & 37 \\
\hline & $35-44$ & 82 & 70 & 70 & 80 & 62 & 80 & 19 & 40 \\
\hline & $45-59$ & 86 & 38 & 70 & 13 & 50 & 13 & 17 & 25 \\
\hline & $60+*$ & 82 & 66 & 62 & 33 & 45 & 33 & 18 & 100 \\
\hline
\end{tabular}

*Total count $\mathrm{N}=3$

Information-seeking behavior and the use of the Internet as an education tool was also seen to be an important use of the Internet. Using the Internet to research the price of products, including goods and services, was more prevalent in Manguinhos than in Brazil as a country. 
Across education and age brackets, prevalence of use remained more or less consistent in this community. Though relatively low, individuals in Manguinhos also used baking and financial services more than the national average (see Table 5 below). Most notable are those who have less than primary school education in Manguinhos of whom 44\% reported using the Internet for banking services compared to $5 \%$ of those across Brazil (CGI, 2011). Individuals also use the Internet to look for jobs and send their resume, particularly those who had completed high school in Manguinhos (72\%) of respondents versus $32 \%$ of those in the national survey (see table 5 below).

Table 5: Prevalence of research behavior via the Internet

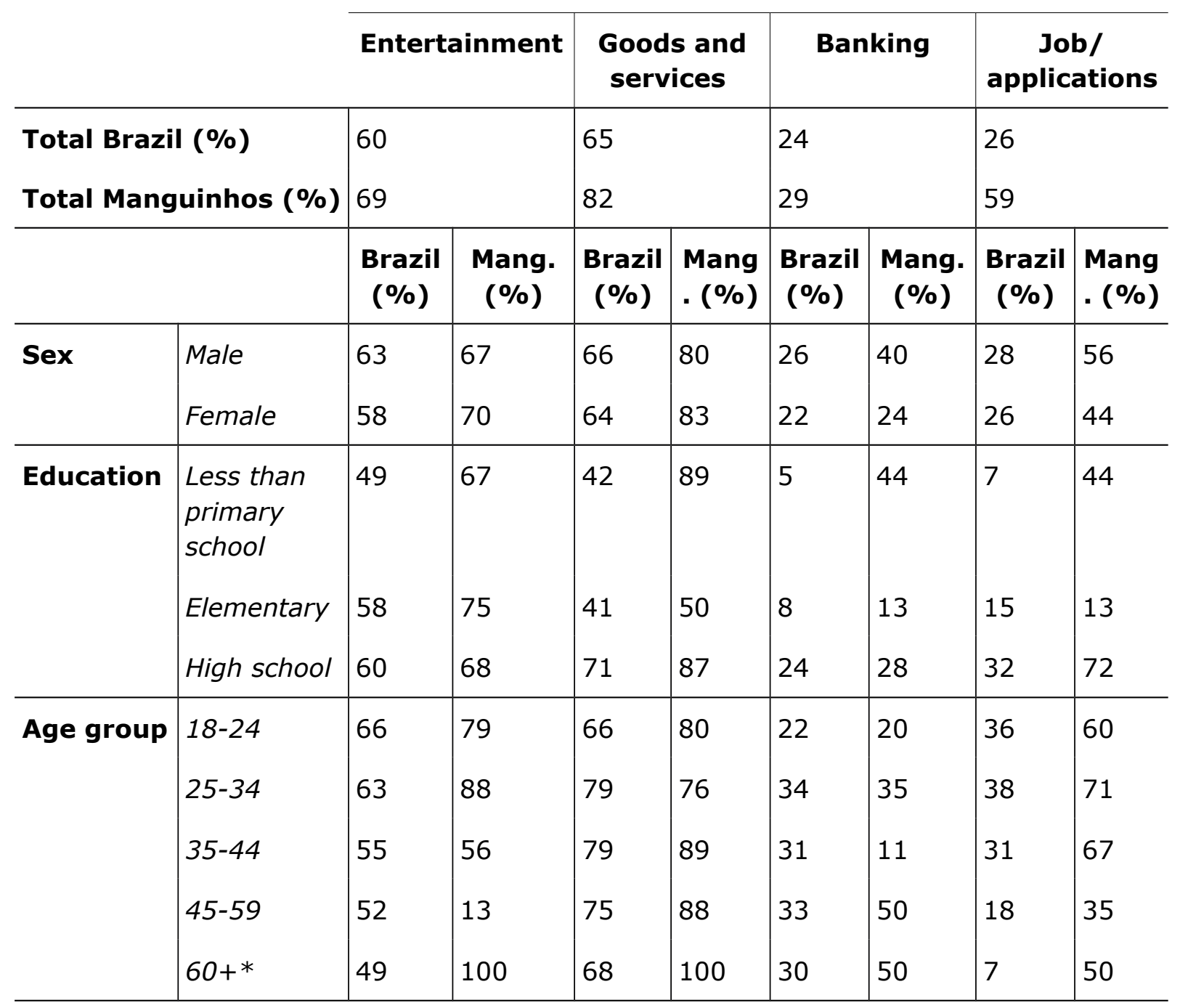

As Wasserman and Richmond-Abbott (2005) found, one of the strongest predictors of Internet use was education level. Those that completed high school were significantly more likely to use the Internet $(94.7 \%$ had ever used the Internet, $p=.001$ ) (Table 6$)$ were more likely to have accessed the Internet for a longer period of time and reported a greater frequency of Internet use. Age was also a strong predictor of Internet use. All $(\mathrm{N}=22)$ participants under the age of 24 reported having ever used the Internet. No significant association was found between social network or email usage and age. Younger people were more likely to report searching for education information online $(p=.03)$ though no significant associations were found between age and other types of on-line research. No significant relationship was found between sex and Internet use. However, women are more likely than men to obtain health information (46.9\% vs. $18.3 \%, p=.046$ ) via social networks as is consistent with other research (WASSERMAN and RICHMOND-ABBOTT,2005). 
Table 6: Associations between education level and Internet use

\begin{tabular}{l|c|c|c|c}
\hline $\begin{array}{c}\text { No formal } \\
\text { education }\end{array}$ & $\begin{array}{c}\text { Incomplete } \\
\text { primary school }\end{array}$ & $\begin{array}{c}\text { Complete } \\
\text { primary school }\end{array}$ & $\begin{array}{c}\text { Incomplete } \\
\text { high school }\end{array}$ & $\begin{array}{c}\text { Complete } \\
\text { high school }\end{array}$ \\
\hline
\end{tabular}

\section{Ever used the Internet}

\begin{tabular}{l|l|l|l|l|l}
\hline Yes & $\mathrm{N}=0$ & $\mathrm{~N}=0$ & $\mathrm{~N}=9$ & $\mathrm{~N}=25$ & $\mathrm{~N}=18$ \\
& $0.0 \%$ & $38.5 \%$ & $52.9 \%$ & $65.8 \%$ & $94.7 \%$ \\
\hline No & $\mathrm{N}=2$ & $\mathrm{~N}=16$ & $\mathrm{~N}=8$ & $\mathrm{~N}=13$ & $\mathrm{~N}=1$ \\
& $100 \%$ & $61.5 \%$ & $47.1 \%$ & $34.2 \%$ & $5.3 \%$ \\
\hline Chi-square & $\mathbf{1 8 . 5 6 2}$ & & & \\
\hline $\mathrm{P}$ & $\mathbf{0 0 1}$ &
\end{tabular}

\section{Interview themes}

\section{The paradox of general Internet use}

Participant use of the Internet is frequent and extensive, however, thematic analysis revealed limitations of Internet use among the study population. Exploring the extent of use and identifying reservations in use allows for a richer understanding of the role of the Internet in this community.

In regard to Internet use, there was an overall sentiment that the Internet is necessary to fully participate in daily activities. An overwhelming majority of participants cited using the Internet for communication through social network participation, online chatting, and email exchange. However, other activities such as playing games, listening to music, conducting basic research, online banking, and online shopping were also popular among participants. One elderly man said: "I think the Internet is... a huge book of grandiose dimension. The Internet is a storage unit with tons of information."

The idea that the Internet is a powerful and ubiquitous source of knowledge for general inquiries was also widely discussed. In one instance, an adult female participant stated, matter of fact, that "Google [was] like [her] father." The association of the Internet with the Patriarchal father figure indicates two things regarding how participants use the Internet. Much like a stereotypical father, the Internet is a trustworthy source of knowledge and information. However, respect is paramount, and abuse is unacceptable. Primary areas of research identified by participants were education, work-related, travel-related or for recreational activities. This metaphor was explicit in the discussion of health-seeking behavior. In general participants believed that using the Internet to disseminate health information, particularly in the form of campaigns or mass communication messages via email or social networks, was very important and beneficial due to wide population reach. For example, an adult female stated that people end up becoming more aware of diseases and can more easily learn of prevalence and incidence rates: "Oh that city, or that place has an outbreak. Or that neighborhood has dengue. The Internet helps us know where infections are occurring." Participants felt strongly that the Internet could provide general information about vaccines and diseases.

However, while participants felt at ease using the Internet to seek general health information such as symptoms of a myocardial infarction or what to expect during pregnancy, comfort was 
greatly diminished when the information being sought had personal significance or relevance. Many participants associated online health-information seeking with the negative act of selfmedication. Moreover, participants recognized that the level of understanding varies between a doctor and a patient, despite health-information being widely available to everyone with Internet access. A majority of participants were aware of the inherent risks they take by participating in online activities such as information seeking and communication. An elderly male participant best exemplified this by saying that "you have to keep one eye on the priest, another on the mass" when using the Internet.

\section{Cognitive dissonance in the Doctor-Patient Relationship}

Results show that participants place very high value on the traditional doctor-patient relationship and that there is a cognitive dissonance when trying to reconcile these relationships in the digital age.

For some, the traditional doctor-patient relationship had already fully occupied the virtual sphere, as is clearly illustrated by the adult female law-student that is friends with her gynecologist on Facebook. The participant explained that she would frequently ask her doctor anything through online social media. She proved to feel very comfortable interacting with her doctor on the Internet, and highlighted the benefit of being able to receive quick responses to her medical inquiries without leaving her home.

Other participants mentioned using online health-related forums to interact with doctors and health professionals outside of their primary care physician. One adult woman spoke enthusiastically about a website she subscribed to for advice on her pregnancy and tips on raising her young child. The participant spoke extensively to the positive nature of her experience and her success in promoting the website to friends and family members, as well as doctors, that were previously unaware of the website's existence.

While online communication with doctors and health professionals was present in some cases, it was uncommon in most. The majority of participants showed awareness of the availability of health information online but were overly concerned with the source of the information as well as their ability to successfully interpret the data. Another major concern was the diagnostic role of the doctor, and the fact that online communication with a doctor or unknown health professional could not replace in-person consults and examinations. Various participants of different ages declared a version of the statement: "the Internet is not a doctor."

When participants were asked how they would attempt to solve and understand the appearance of a hypothetical lump on their body, they responded they would first find a Doctor. One young-adult participant stated confidently that she asked the doctor everything whenever she had a medical or health-related question. Other participants were also enthusiastic about their decision to seek help from their Doctors and the health clinic. Reliance on the doctor for health-related information was pervasive. One adult woman said, "If you're sick it's the [heath] post, anything, everything is at post." The results show that participants were divided regarding health-related use of the Internet.

\section{Perception of Internet value}

Aside from having access to health information and health-care professionals, participants identified other reasons why the Internet was supportive of their well being. The first and major sub theme that emerged regarding the value of the Internet relates to the promotion of social inclusion. Every participant identified using social media or email or both to communicate with distant family members, participate in school discussions, make and maintain friendships, as well as stay up to date with current events and social happenings. One 
young-adult female said, "Facebook is today's gossip central, without it you don't find out about anything."

Moreover, participants conveyed awareness of the role the Internet might play on education. The majority of participants mentioned using the Internet for educational purposes, which encompassed searching for educational programs or schools, researching information for class, or helping their children with homework assignments. In one instance, a mother explained how her child searched the Internet for information after failing a test at school: "he got a zero on his test, the teacher asked what was cholera, he said, mom I'm going to look on the Internet to see what it is...So he got a zero on the cholera exam, so he went to the computer, to find out what cholera is. It seems that now he knows."

In addition, the Internet was identified as a money and time saving tool. The majority of participants mentioned the increased ease and speed of communicating with people over the Internet. It was widely assumed that everyone likes the Internet and knows how to chat with people online. Moreover, many participants indicated they were "online all day" to chat, pay bills, send work-related emails, and even listen to online talk shows. For some, the Internet provides a way to save money and increase their income. One young-adult female explained the benefits of online shopping in terms of easily finding the lowest price for a given item. Another participant, adult female, said she could run her Beauty salon at lower costs by purchasing wholesale products online.

\section{Discussion}

The purpose of this research was to gain a rich understanding how low-income people value and use the Internet, both for general activities and health-related information and communication. The goal of the research was to understand perceptions of the Internet and to understand where digital exclusion still exists and how Internet use can be better targeted for public health interventions.

This study showed improvements in closing the digital divide among low-income residents. The high frequency of use ( $89 \%$ reported having used the Internet in the past week) and the prevalence of computers in the home show the value of Internet use among this population. One way the digital divide is closing is in the variety of ways in which people engage with the Internet such as social media, health seeking behavior, and education as evidenced in the qualitative interviews. Among those with relatively homogenous income levels, gaps in education account for a large percentage of the digital divide. Searching for job-related information was used more often by those who had a high school education (72\%) than those who had completed less than primary school (44\%). However, some activities such as the use of online communication tools were enjoyed by the majority of participants, bearing no relationship with level of education. Of Internet users with no education, $80 \%$ had used social networks.

Individuals regarded the Internet as a valuable and indispensable tool. This value placed on the Internet is evidenced by the high percentage of individuals whose primary access location is in their own home (58\%) of those who had previously used the Internet. Individuals believed that the Internet's most important quality is its ability to answer questions and transfer knowledge to the user, which is best described by the quote "Google is like my Father." This knowledge was shown to promote social inclusion, education, and behave as a time and money saving tool. The association between Google (the Internet) and "Father" (allknowing and powerful) is telling of the Internet's significance in this community. The metaphor is also important when trying to understand participant health-seeking behaviors as they were often limited to general health questions rather than personal health concerns. Individuals 
were more likely to report researching an illness rather than posting information about themselves or a family member online. Much like a father, there are certain topics that are offlimits, and it appears that participants are still very much reluctant to share their personal health problems with their father (i.e. Google).

Our results also found that individuals are more often passive recipients of information rather than actively seeking out health. These results slightly contradict previous research that found that individuals actively search for health information (GARBIN, 2008). Though some individuals are highly involved in Internet-based health research (for example, the woman who is Facebook friends with her gynecologist), this is certainly not the norm. In the qualitative interviews, many respondents reported seeing Facebook posts about health campaigns and/or diseases. They do not seek out this information, rather, health knowledge, like other pieces of information permeate their engagement in social networks. Quantitative results show that $40 \%$ of respondents reported receiving health information via social networks whereas only $20 \%$ had informed someone else about health. These aggregate results demonstrate the trepidation many feel to seek out information beyond what finds them. This finding has significant implications for further public health research. Rather than disseminating health information through health-specific websites, public health experts should tap into social networking sites like Facebook or Twitter to reach a broad population and provide succinct, accurate facts.

Although individuals ascribed importance to research possibilities and dissemination of information online, this was neither the online activity they engaged in the most, nor the activity that brought about feelings of wellbeing. Online communication was widely discussed and seemed to be highly influential in the individual's emotional wellbeing and ability to relate to others. This was seen especially in parents seeking to maintain familial bonds with their children and family members that live or work in other states. In general, those with lower involvement in online social network activities or a sense of apathy towards Internet use were also more likely to speak of depression or poor self-esteem. In this community, inclusion online can help contribute to a greater sense of citizenship despite being on the fringe of society. Marginalization from city services such as trash removal and sanitation, as well as ubiquitous poverty and violence despite pacification of the favela earlier this year, make it a particularly vulnerable population.

Furthermore, participants maintained a strong preference to seeking health information at the health clinic as opposed to the Internet, consistent with findings from Välimäki (2007). Interpersonal relationships and a sense of belonging is of utmost importance to this insular community, an attitude that extends to one's relationship with his or her physician. Information obtained online supplemented or clarified their doctor's suggestions rather than replacing him or her.

This research demonstrates the opportunity the Internet provides in the health system reaching these populations. Of those who use the Internet, $85 \%$ had taken part in a social network, much higher than the national average of $69 \%$ of those surveyed. The high prevalence of social network use among this community, even among those with no education ( $80 \%$ of respondents) indicates a vehicle through which health information could be disseminated. Individuals also reported high prevalence of instant message use (66\% of respondents) and using email ( $71 \%$ of respondents). By acknowledging widespread engagement in social networks and online communication platforms, healthcare professionals can communicate more readily with patients, potentially improving quality of care. 


\section{Conclusion}

Due to the socio-environmental profile of Manguinhos and on-going challenges to provide basic social needs, online communication technology is of paramount importance. This study seeks to understand not only the role of health-seeking behavior, but also the type of Internet use among low-income individuals and the perceived value. This will allow for targeted public health interventions via the Internet as well as other communication technologies. Creating online spaces for healthcare professionals to communicate with patients is likely to empower the patient to speak openly about his questions, fears, and experiences. Not only will the patient benefit from discussing his or her health-related online experience with the doctor, but also the doctor will be able to gauge the patients' comprehension of the issue, which may lead to increased success in delivery of care. If harnessed effectively, the Internet has the potential to improve the health of the poorest citizens and change the profile of development.

\section{References}

BENOTSCH, E.G., KALICHMAN, S., WEINHARDT, L.S.. HIV/AIDS patients evaluation of health information on the Internet: the digital divide and vulnerability to fraudulent claims. Journal of Consulting and Clinical Psychology, v. 72, n. 6, p1004-11, 2004.

CENTRO DE ESTUDOS SOBRE AS TECNOLOGIAS DA INFORMAÇÃO E DA COMUNICAÇÃO. .TIC

Domicílios e usuários 2011. Retrieved September 24, 2012 Available from:

<http://www.cetic.br/usuarios/tic/2011-total-brasil/index.htm.>. Cited 20 Sept. 2012.

COURSARIS, C. K; LUI, M. An analysis of social support exchanges in online HIV/AIDS selfhelp groups, Computers in human Behavior, v.25, n.4, p 911-918, 2009.

GARBiN, H. B.; PEREIRA NETO, A.F.; E GUiLAM, M. C. R. . The Internet, expert patients and medical practice: an analysis of the literature. Interface - Botucatu, v.12, n.26p. 579588,2008 .

FERREIRA, P,L. Criação da versão portuguesa do MOS SF-36. Parte I - Adaptação cultural e linguística. Acta Med Port. v.13, n.1-2, p55-66, 2000.

FÓRUM discute mobilização contra violência em Manguinhos. ENSP.. Available from:. <http://ensp.fiocruz.br/portal-ensp/informe/site/materia/detalhe/1107>. Cited 20 Sept. 2012.

GUTIÉRREZ, L.H. ; GAMBOA, L. F. Determinants of ICT usage among low-income groups in Colombia, Mexico and Peru. The information society, v.26, p.346-363, 2010.

JAEGER, P.T. ; BERTOR, J. C.. The Intersection of public policy and public access: digital divides, digital literacy, digital inclusion and public libraries. Public library quarterly, v.31, n.1, 2012..

JAMES, J. Are changes in the digital divide consistent with global equality or inequality? The Information Society, v.27,n.121-128,2011.

KALICHMAN, S. C.; BENOTSCH, E. G.; WEINHARDT, L. Health-related internet use, coping, social support, and health indicators in people living with HIV/AIDS: preliminary results from a community survey. American Psychology, v.22, n.1,p.111-116, 2003.

KIM, J. ;E KIM, S.. Physicians' perception of the effects of Internet health information on the doctor-patient relationship. Informatics for Health \& Social Care, v.34, n.3, p.136-148, 2009. 
MCMULLAN, M. Patients using the Internet to obtain health information: how this affects the patient-health professional relationship. Patient Education and Counseling, v.63, n.1-2,p.2428,2006 .

NEUHAUSER, L.; KREPS, G. L.. Rethinking Communication in the E-health Era. Journal of health psychology, v.8,n.1,p.7-23,2003.

ROSSOTTI, R.; GABRIELLI, E.; GERVASONI, C..). HIV education and counseling using Facebook: a possible new approach. Journal of telemedicine and telecare, v.18, n.4, p.p. 239240, 2012.

SAMAL, L.; SAHA, S.; CHANDER, G. Korthuis, P. T., Sharma, R. K., Sharp, V., Cohn, J., et al. Internet health information seeking behavior and antiretroviral adherence in persons living with HIV/AIDS. AIDS patient care and STDs, v.25,n.7,p.445-9, 2011,

SMITH-MENEZES, A; TRIBESS, S.. Prevalência e fatores associados à percepção negativa da saúde em pessoas idosas no Brasil. Rev Bras Epidemiol, v.15(, n.1, p.49-62, 2012.

SOUZA, J. F. R.;, MARINHO, C. L. C., ; GUILAM, M. C. R.. Consumo de medicamentos e internet: análise crítica de uma comunidade virtual. Revista da Associação Médica Brasileira, v.54, n.3, p. 225-231, 2008.

TRINDADE, C. "Não se faz omelete sem quebrar os ovos": política pública e participação social no PAC Manguinhos - Rio de Janeiro. 2012 Tese (Doutorado) -. Universidade Federal Fluminense, Instituto de Ciências Humanas e Filosofia, Departamento de História, 2012.

VÄLIMÄKI, M.; NENONEN, H.; KOIVUNEN, M. et al.). Patients' perceptions of Internet usage and their opportunity to obtain health information. Medical Informatics \& The Internet in Medicine, v.32, n.4,p.305-314, 2007.

VASCONCELLOS-SILVA, P. R., CASTIEL, L. D., BAGRICHEVSKY, M. et al., \& Griep, R. H. (2011). Panacéias disseminadas pela Internet e pacientes vulneráveis: como conter um mercado de ilusões? Revista Panamericana de Salud Pública, v.29, n.6,p. 469-474, 2011.

WASSERMAN, I. M.; RICHMOND-ABBOTT, M. . Gender and the Internet: causes of variation in access, level and scope of use. Social Science Quarterly, v.86,n.1,p.252-270, 2005.

YBARRA, M. L.; KIWANUKA, J.; EMENYONU, N.et al., Internet useamong Ugandan adolescents: implications for HIV intervention. PLoS medicine, v.3, n.11,p.33, , 2006.

\section{Acknowledgment}

This article is the result of a research project named "Internet and health: a study on the perception of residents of Manguinhos (RJ)" approved by the Research Ethics Committee of the National School of Public Health (FIOCRUZ) through the "Certificate of Introduction to Ethics Assessment (CAAE)" - Number 09305112.2.0000.5240. This study did not receive any form of funding. The findings and conclusions in this report are those of the authors and do not necessarily reflect the views of ENSP or the CSEGF.

\section{Author Disclosure Statement}

No competing financial interests exist. 


\section{Appendix II: Roteiro da Entrevista/ Interview Script}

1. O que significa a palavra "saúde" para você?

(What does "health" mean to you?)

2. Você acha que sua saúde está legal?

(Do you consider yourself in good health?)

3. Tem alguma coisa na sua saúde que poderia mudar?

(Is there any aspect of your health and wellbeing that could be different?)

4. Tem algúm hábito que você gostaria de mudar?

(Do you have any habits you would like to change?)

5. Que tipo de coisas você faz na Internet?

(What kinds of activities do you engage in on the Internet?)

6. Explica como o Facebook (ou outra rede virtual) faz parte da sua vida

(Explain how Facebook (or another online social network) is part of your life.)

7. Vamos supor que você quer fazer uma nova amizade na Internet. O que você faz para conhecer essa pessoa? Explica como você acha que deveria evoluir a amizade.

(Suppose you would like to make a new friendship on the Internet. How do you go about meeting someone? Explain how you believe the friendship should evolve.)

8. Alguém que você não conhece pessoalmente já falou com você pela Internet? Explica como você se sentiu com essa experiência.

(Has someone you do not know personally ever contacted you through the Internet? If yes, explain how you felt with this experience.)

9. Que tipo de pesquisas você já fez na Internet? Você curtiu?

(What kind of research have you done on the Internet? Did you enjoy it?)

10. Você acha que existe informação na Internet que pode ajudar você cuidar de alguém como a sua familia, filhos, amigos?

(Do you believe that online information has the ability to help you take care of someone such as your family members and friends?)

11. Se você tem uma questão medica, qual é o primeiro lugar onde você procura informação? (What is the first place you go to if you have a medical question?)

12. Você já falou com o seu médico sobre as informações que você achou?

(Have you ever spoken to your Doctor about the medical information you found on your own?)

13. Vamos imaginar que você descobre um coroço no seu corpo. O que você faria para começar entender ou resolver a situação? Onde você buscaria informação? 
(Suppose you discover a lump on your body. How would you go about understanding or solving the situation? Where would you seek basic information?)

14. Você já viu alguma campanha na Internet (fotos/email/etc) que fala de uma doença/ questão de saúde? (curtiu/compartilhou?)

(Have you ever seen a campaign on the Internet for a disease or health-related topic? Did you "like" or "share" it with friends?)

15. Que tipo de relação existe entre a sua saúde e a Internet?

(What kind of relationship exists between your health and the Internet?)

Recebido 27.03.2013

Aceito 21.06.2013 